\title{
FAKTOR-FAKTOR YANG MEMPENGARUHI PURCHASE DECISION INVOLVEMENT GENERASI MILLENNIAL DI TRAVELOKA
}

\author{
Ridho Ryswaldi \\ Program Studi Magister Manajemen, Fakultas Ekonomi, Universitas Andalas, Indonesia \\ ridhoryswaldi@gmail.com \\ Vera Pujani \\ Program Studi Magister Manajemen, Fakultas Ekonomi, Universitas Andalas, Indonesia \\ verapujani@eb.unand.ac.id
}

\begin{abstract}
ABSTRAK
Penelitian ini dilakukan bertujuan untuk mengetahui faktor-faktor yang mempengaruhi minat atau ketertarikan generasi milenial terhadap purchase decision involvement yang dimediasi oleh trust. Variabel independent pada penelitian ini ada social media usage, eWOM, third party recognition, dan legal framework. Teknik pengumpulan sampel dilakukan dengan non probability sampling dengan purposive sampling. Generasi milenial pada penelitian ini memiliki rentang umur 18-34 tahun. Responden merupakan mahasiswa S1 dan S2 di Kota Padang. Jumlah responden pada penelitian ini sebanyak 216 responden. Teknik analisis data yang digunakan dalam penelitian ini adalah Maximum Likelihood. Pada penelitian ini diperoleh social media usage, eWOM, dan legal framework berpengaruh signifikan positif terhadap purchase decision involvement, sementara third party recognition tidak berpengaruh. Untuk mediasi oleh trust, social media usage, eWOM, third party recognitiom, dan legal framework, berpengaruh terhadap purchase decision involvement.
\end{abstract}

Kata Kunci: social media usage, eWOM, third party recognitiom, legal framework, trust, purchase decision involvement

\begin{abstract}
This research was conducted aiming to find out the factors that influence interests of millennial generation towards purchase decision involvement mediated by trust. The independent variable in this study is social media usage, eWOM, third party recognition, and legal framework. The sample collection technique is done by non probability sampling with purposive sampling. Millennial generation in this study has an age range of 18-34 years. Respondents are undergraduate and graduate students in the city of Padang. The number of respondents in this study were 216 respondents. The data analysis technique used in this study was Maximum Likelihood. In this study obtained social media usage, eWOM, and legal framework have a significant positive effect on purchase decision involvement, while third party recognition has no effect. For mediation by trusts, social media usage, eWOM, third party recognitiom, and legal framework, affect purchase decision involvement.
\end{abstract}

Keywords: social media usage, eWOM, third party recognitiom, legal framework, trust, purchase decision involvement 
PENDAHULUAN

Fenomena perubahan gaya hidup masyarakat baik dari sosial dan budaya salah satunya dipengaruhi oleh perkembangan teknologi internet maupun alat telekomunikasi yang sangat pesat (Purnasari \& Yuliando, 2015). Perubahan yang terjadi dapat dirasakan dengan kemudahan yang ditawarkan oleh internet. Dewasa ini, semua orang pada umumnya tahu akan hadirnya teknologi internet dalam kehidupan sehari-hari.

Pemanfaatan teknologi digunakan pada industri pariwisata guna meningkatkan produktivitas. Dengan hadirnya online travel agent merupakan bentuk perkembangan teknologi yang dimanfaatkan oleh industri pariwisata. Jin dan rekan (Jin et al , 2007) mendefinisikan OTA sebagai penyedia informasi perjalanan online yang membantu pelanggan membeli tiket perjalanan mereka dan kenyamanan terkait lainnya. Salah satu online travel agent yang ada di Indonesia adalah Traveloka. Traveloka merupakan salah satu online travel agent yang ada di Indonesia. Konsep bisnis yang ditawarkan Traveloka adalah transparansi harga dan update harga real time. Traveloka juga menyediakan pemesanan tiket perjalanan wisata, tiket kereta api, tiket pertunjukan seni, paket wisata, dan voucher telepon. Traveloka terus berinovasi mengikuti perkembangan zaman.

Berdasarkan survey yang dilakukan Asosiasi Penyelenggara Jasa Internet Indonesia (APJII), pengguna internet $\mathrm{di}$ Indonesia pada tahun 2016 mencapai 132,7 juta. Pada tahun 2017 pengguna internet di Indonesia naik menjadi 143,26 juta dari total jumlah penduduk Indonesia pada tahun 2017 sebanyak 262 juta. Bertumbuh 10,56 juta pengguna dari tahun 2016 (APJII, 2017). Dari hasil survey yang dilakuan APJII pada tahun 2017, didapatkan data pengguna internet sebesar $16,68 \%$ berusia $13-18$ tahun, $49,52 \%$ berusia 19-34 tahun, 29,55\% berusia 35-54 tahun dan $4,24 \%$ berusia di atas 54 tahun. Dapat disimpulkan pengguna internet banyak berusia 19-34 tahun.

$$
\text { Menurut Gura } \quad \text { u }
$$
pengelompokkan generasi dibagi ke dalam tiga generasi. Generasi baby boomer untuk yang lahir antara tahun 1946 sampai tahun 1960. Generasi X untuk yang lahir antara tahun 1961 sampai tahun 1979. Generasi milenial untuk yang lahir antara tahun 1980 sampai tahun 
1999. Para peneliti mengelompokkan ke dalam beberapa kriteria berdasarkan tahun kelahiran, tetapi para peneliti sepakat bahwa secara umum, masing-masing kelompok generasi memiliki sikap dan perilaku yang sama (Parment, 2013).

Pada tahun 2020, Indonesia akan memiliki generasi milenial dengan rentang usia 20 tahun sampai dengan usia 40 tahun terbanyak. Rentang usia 20 sampai 40 tahun merupakan tulang punggung perekonomian Indonesia masa datang.

Sebelum melakukan pembelian di online travel agent, konsumen akan menaruh minat terhadap Traveloka. Adanya minat dari konsumen ini disebut dengan purchase decision involvement. Selama tahap keputusan pembelian, konsumen memiliki minat dan kepedulian yang merupakan konsep pola pikir konsumen dengan berbicara tentang antisipasi dalam keputusan pembelian. Karena ada banyak alternatif dan pilihan merek yang tersedia di pasar, konsumen mempertimbangkan pilihan mana yang merupakan pilihan paling tepat bagi mereka yang menghasilkan pilihan yang tepat selama proses pengambilan keputusan, secara tidak langsung pada niat (Jalilvand \& Samiei, 2012).
Perilaku keputusan pembelian pada millennial sangat menarik untuk diteliti karena populasinya yang sangat besar.

Dalam transaksi online, kepercayaan memainkan peran yang sangat penting, karena kepercayaan akan menimbulkan dorongan di dalam diri konsumen untuk melakukan kegiatan transaksi secara online. Hal ini dikarenakan calon pembeli tidak dapat melihat secara langsung tentang produk yang diperdagangkan. Kepercayaan berperan sangat penting dalam membina hubungan, terutama dalam pembelian melalui situs jejaring sosial maupun pada usaha jasa yang penuh dengan risiko dan kurangnya informasi di antara pihak penjual dan pembeli.

Pencarian informasi terhadap millennial dapat menarik minat dan kepedulian millennial terhadap suatu merek. Faktor pertama melalui media sosial. Saat ini media sosial dijadikan salah satu gerakan baru di dunia pemasaran, berbagai media sosial muncul dengan keunggulan yang dimiliki.

Faktor kedua, informasi yang ingin dicari oleh generasi milenial tentang Traveloka dapat melalui eWOM. eWOM merupakan cara yang paling efektif untuk menciptakan suatu keputusan pembelian saat ini. Zhang dan rekan 
(Zhang et al, 2010) mengatakan bahwa internet saat ini sangat diberdayakan konsumen untuk berbagi informasi dengan mudah diakses dan sebagian besar konsumen dapat memberitahukan pengalamannya melalui internet dan mempengaruhi konsumen lainnya melalui $e W O M$.

Faktor ketiga yang memberi konsumen rasa aman dalam bertransaksi di e-commerce adalah third party recognition. Menurut (Bojang, 2017) kebijakan jaminan yang dikombinasikan dengan sertifikat pihak ketiga yang tepercaya dan independen akan sangat membantu untuk mengembangkan dan mempertahankan kepercayaan konsumen. Contoh dari pihak ketiga yang terlibat ke dalam Traveloka adalah Rapid SSL, Verisign, IATA dan ASITA. Lembaga ini berfungsi sebagai bentuk pengakuan terhadap kehadiran Traveloka. Dengan adanya jaminan yang diberikan oleh pihak ketiga akan membuat konsumen merasa resiko bertransaksi di Traveloka semakin sedikit. Pihak ketiga akan memberikan jaminan transaksi yang aman sehingga akan membentuk kepercayaan pada konsumen.
Faktor keempat yang ingin diteliti dalam penelitian ini adalah legal framework. Legal framework akan memberikan kepastian hukum tentang keamanan bertransaksi secara online. Keamanan memiliki hubungan yang positif dan signifikan dalam mempengaruhi keputusan pembelian (Raman, 2015). Secara umum, konsep keamanan mengacu pada kemampuan untuk melindungi terhadap ancaman potensial. Namun, dalam lingkungan online, keamanan didefinisikan sebagai kemampuan dari website perusahaan online untuk melindungi informasi konsumen dan data transaksi keuangan mereka dicuri selama terjadi hubungan di antara mereka.

Purchase decision involvement dipengaruhi oleh minat dan ketertarikan konsumen dalam memilih salah satu produk atau jasa yang akan digunakan. Faktor-faktor yang mempengaruhi purchase decision involvement salah satunya adalah sosial media usage, eWOM, third party recognition dan legal framework yang dimediasi oleh trust. 


\section{TINJAUAN TEORI DAN}

\section{PENGEMBANGAN HIPOTESIS}

\section{Purchase Decision Involvement}

Keterlibatan dapat didefinisikan sebagai variabel yang dipengaruhi oleh motivasi yang mengarahkan konsumen ke perilaku tertentu (Houston, 2016). Konsumen akan melibatkan motivasi terhadap perilaku keputusan pembelian. Keterlibatan keputusan pembelian (purchase decision involvement) merupakan keterlibatan konsumen terhadap proses pembelian.

Menurut Mittal (1989), purchase decision involvement adalah untuk menunjukkan perbedaan antara keterlibatan produk dan proses keputusan yang terkait dengan pembelian suatu produk. Dalam melakukan hal itu, purchase decision involvement didefinisikan sebagai keadaan pikiran yang tidak responsif yang mengidentifikasi manfaat dari pembelian produk tertentu, mengulangi perbedaan antara lain: (1) Bertahan; (2) Keterlibatan situasional; (3) Perilaku responsif yang memanifestasikan diri mereka dalam proses pengambilan keputusan.

\section{Social Media Usage}

Social Media merupakan layanan online yang mana penggunanya dapat mempublikasikan, mengedit, membuat, mendesain, dan berbagi konten yang berbeda. Media sosial terdiri dari situs jejaring sosial, komunitas online, layanan yang dibuat pengguna seperti blog, situs berbagi video, situs ulasan atau peringkat online, dan dunia game virtual (Krishnamurthy \& Dou, 2008). Hubungan dengan konsumen dapat diperkuat secara luas dengan memfasilitasi media sosial sebagai interaksi dengan media sosial meningkatkan keterlibatan konsumen dengan produk dan layanan (Doorn et al, 2010).

Kemudahan mengajukan keluhan pada platform media sosial memungkinkan konsumen untuk berbicara. Mengharapkan partisipasi perusahaan pada platform tersebut, penggunaan media sosial pada konsumen dapat sebagai wadah untuk menampung keluhan yang lebih cepat dibandingkan menghubungi perusahaan langsung (Ma et al, 2015). Konsumen yang senang akan menghargai perusahaan dan bersedia memberikan pujian. Melibatkan konsumen secara online melalui media sosial menjadi keharusan bagi para praktisi agar didapatkan 
tanggapan yang cepat terhadap suatu produk atau jasa. Media sosial dapat dijadikan sebagai sumber marketing intelligence.

\section{Electronic Word of Mouth}

\section{Electronic Word of Mouth (eWOM)} merupakan bentuk komunikasi dari mulut ke mulut melalui media online yang tidak hanya bentuk komunikasi perseorangan, tetapi lebih banyak tersebar melalui jaringan internet world wide web. Informasi yang ada pada $e W O M$ adalah informasi positif, negatif atau netral tentang sebuah produk atau jasa yang diberikan oleh pelanggan pada internet (Hennig-Thurau et al, 2004).

Wu dan Wang (2011) mendefinisikan eWOM sebagai pertukaran pengetahuan konsumen secara online. eWOM merupakan suatu bentuk komunikasi tertulis melalui media internet yang dilakukan oleh konsumen potensial atau konsumen masa kini (hal ini dikenal juga sebagai interaksi consumer to consumer) (You et al, 2015).

Kesimpulan yang dapat ditarik dari paparan di atas yaitu $e W O M$ merupakan suatu bentuk media yang memberikan konsumen kesempatan untuk bertukar pikiran atau informasi pengalaman konsumen tentang sebuah produk yang telah digunakan atau dirasakan. Media ini juga dapat dijadikan sebagai wadah untuk memberikan evaluasi atau masukan terhadap produk melalui platform media sosial maupun website. Evaluasi dan masukan ini akan menjadi bahan panduan konsumen untuk mengumpulkan informasi sebelum melakukan aktifitas pembelian. Dengan adanya $e W O M$, konsumen yang ingin melakukan aktifitas pembelian akan mendapatkan evaluasi yang telah digunakan atau dirasakan konsumen sebelumnya.

\section{Third Party Recognition}

Third Party Recognition dapat membantu untuk menyimpulkan beberapa risiko transaksi online dan meningkatkan kepercayaan secara keseluruhan (Mcknight et al, 2002). Adaptasi dari teori sosiologi dan pemasaran, dapat disimpulkan bahwa kepercayaan dapat ditransfer (Stewart, 2001). Ini merupakan persyaratan mendasar dalam melakukan e-commerce. Khususnya, kepercayaan dapat ditransfer dari individu atau kelompok tepercaya.

Misalnya, sebagian besar pelanggan mungkin tidak mempercayai tenaga penjualan dalam pertemuan awal, dan mereka mungkin 
merasa tidak yakin tentang klaim yang dibuat oleh tenaga penjualan. Dimasukkannya laporan perdagangan memungkinkan transfer kepercayaan dan mengatasi kurangnya kepercayaan dari tenaga penjualan. Demikian pula, dalam konteks belanja internet, konsumen tidak memiliki kontak fisik dengan pedagang internet. Dengan adanya third party recognition dapat membantu dalam mempromosikan kepercayaan dalam belanja internet.

Oleh karena itu, ini dapat mengurangi ketidakpastian konsumen ketika berhadapan dengan situs atau orang baru. Institutional based trust menyiratkan bahwa jika terjadi kesalahan, institusi akan berusaha untuk menjaga kepercayaan dan dengan demikian mengurangi risiko kepada pelanggan (Salam et al, 2003). Dengan adanya keterlibatan institusi akan memberikan konsumen rasa aman dan akuntabilitas. Menurut (Pavlou \& Gefen, 2004) third party recognition dapat berfungsi dengan empat cara: (1) mekanisme feedback (bagian dari kepercayaan orang lain terhadap pembeli / penjual); (2) layanan escrow (memegang pembayaran sampai pembeli puas dengan transaksi); (3) jaminan kartu kredit; (4) kepercayaan pada perantara pasar yang disediakan melalui kepercayaan pada lembaga pihak ketiga).

Struktur lain terjadi jika pihak ketiga menerima barang yang ditukar dan kemudian meneruskannya dengan cara yang sesuai (Ray et al, 2005). Dengan demikian konsumen dapat merasa yakin akan setiap transaksi yang dilakukan melalui perantara.

\section{Legal Framework}

Legal Framework merupakan suatu perlindungan konsumen online yang melakukan transaksi elektronik. Perlindungan konsumen adalah semua upaya yang menjamin kepastian hukum bagi konsumen. Berdasarkan Pasal 1 nomor 1 Hukum Perlindungan Konsumen "perlindungan konsumen adalah seтиa upaya yang menjamin kepastian hukum untuk memberikan perlindungan kepada konsumen".

Dengan diterapkannya perlindungan hukum bagi konsumen dalam transaksi $e$ commerce di era perdagangan global, posisi konsumen akan dilindungi oleh UndangUndang. Posisi mereka juga dapat diminimalisir dari penyalahgunaan pengusaha 
untuk mencapai laba maksimal (Wahyuni, 2003).

Perjanjian e-commerce juga diatur dalam pasal 18 ayat 1 UU No. 11 Tahun 2008 tentang Informasi dan Transaksi Elektronik (IT). Undang-undang menyatakan bahwa Transaksi Elektronik dituangkan ke dalam kontrak elektronik yang mengikat para pihak. Transaksi elektronik biasanya diwujudkan dalam bentuk kontrak elektronik (kontrak online) yang berisi dokumen elektronik transaksi atau perdagangan elektronik.

Esensi perlindungan hukum konsumen diperlukan karena konsumen dalam transaksi e-commerce berada dalam posisi yang lemah. Perbedaan kepentingan antara bisnis dan konsumen akan terjadi manfaat yang didapatkan tidak sama. Adanya perlindungan hukum bagi konsumen diharapkan dapat memberikan keseimbangan posisi hukum antara konsumen dan bisnis dalam transaksi $e$ commerce.

Sofie (2003) menyatakan bahwa keinginan untuk dicapai dalam perlindungan konsumen adalah menciptakan rasa aman bagi konsumen untuk memenuhi kebutuhan mereka.

\section{Trust}

Sebelum konsumen memiliki minat beli ataupun membuat keputusan pembelian, konsumen perlu percaya terlebih dahulu pada produk yang akan dibeli tersebut. Kepercayaan sangat relevan dengan pembelian konsumen online yang secara positif mempengaruhi niat pembelian (Jarvenpaa \& Vitale, 2000). Untuk mempertahankan hubungan dengan konsumen, menciptakan kepercayaan online adalah salah satu faktor penting karena merupakan salah satu alasan untuk situs web yang sukses (Koufaris \& Hampton-sosa, 2004)).

Menurut (Meskaran et al, 2013), trust diketahui sebagai faktor yang penting dalam hubungan pembeli-penjual dan minat pembelian online pada e-commerce Kepercayaan dapat didefinisikan sebagai kesediaan konsumen untuk mengantisipasi kemungkinan kerugian dalam proses belanja (Gefen et al, 2003). Kepercayaan dapat dianggap sebagai suatu perilaku. Dengan adanya kepercayaan akan semakin meningkatkan minat dan ketertarikan konsumen terhadap suatu produk atau jasa. 


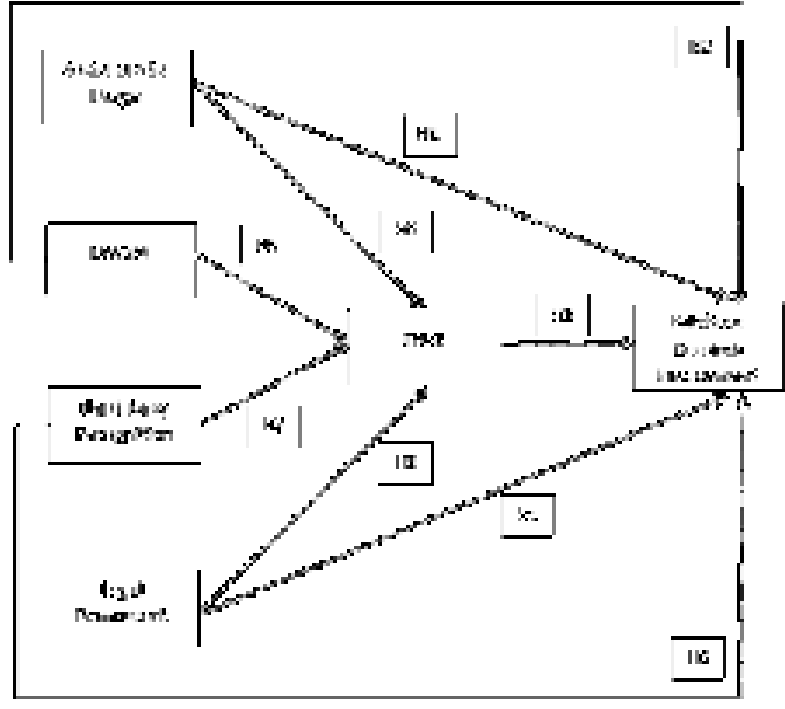

Gambar 1. Kerangka Penelitian

Berdasarkan penjelasan di atas, maka kerangka konseptual penelitian ini dapat digambarkan pada Gambar 1.

Hipotesis merupakan hubungan antara dua atau lebih variabel yang dituangkan ke dalam bentuk pernyataan yang dapat diuji. Pada penelitian ini terdapat Sembilan hipotesis, yaitu:

H1 : Social media usage mempunyai pengaruh signifikan terhadap purchase decision involvement pada konsumen traveloka.

$\mathrm{H} 2$ : eWOM mempunyai pengaruh signfikan terhadap purchase decision involvement pada konsumen traveloka.

H3 : Third party recognition mempunyai pengaruh signifikan terhadap purchase decision involvement pada konsumen traveloka.

H4 : Legal Framework mempunyai pengaruh signifikan terhadap purchase decision involvement pada konsumen traveloka H5 : Trust mempunyai pengaruh signifikan terhadap purchase decision involvement pada konsumen traveloka.

H6 : Social media usage mempunyai pengaruh signifikan terhadap purchase decision involvement yang dimediasi oleh trust pada konsumen traveloka.

$\mathrm{H7}$ : eWOM mempunyai pengaruh signfikan terhadap purchase decision involvement yang dimediasi oleh trust pada konsumen traveloka.

$\mathrm{H} 8 \quad$ : Third party recognition mempunyai pengaruh signfikan terhadap purchase decision involvement yang dimediasi oleh trust pada konsumen traveloka.

H9 : Legal framework mempunyai pengaruh signfikan terhadap purchase decision involvement yang dimediasi oleh trust pada konsumen traveloka. 
Tabel 1. Operasionalisasi Variabel Penelitian

\begin{tabular}{|c|c|c|c|c|}
\hline Variabel & Definisi & Indikator & Skala & Sumber \\
\hline $\begin{array}{l}\text { Social } \\
\text { Media } \\
\text { Usage }\end{array}$ & $\begin{array}{l}\text { Penggunaan } \\
\text { sarana media } \\
\text { online dalam } \\
\text { pembelian }\end{array}$ & $\begin{array}{l}\text { 1. Fungsi media sosial } \\
\text { 2. Mengamati produk pesaing } \\
\text { 3. Penjualan dan promosi } \\
\text { 4. Event } \\
\text { 5. Hubungan sosial } \\
\text { 6. Media sosial dan merek } \\
\text { 7. Tren di media sosial } \\
\text { 8. Media sosial bagi konsumen }\end{array}$ & Likert 1-5 & $\begin{array}{l}\text { Rapp et al., } \\
2013\end{array}$ \\
\hline EWOM & $\begin{array}{l}\text { Review terhadap } \\
\text { produk atau jasa } \\
\text { melalui online }\end{array}$ & $\begin{array}{l}\text { 1. Komentar baik produk } \\
\text { 2. Komentar positif produk } \\
\text { 3. Rekomendasi produk } \\
\text { 4. Membaca ulasan produk } \\
\text { 5. Percaya ulasan produk }\end{array}$ & Likert 1-5 & $\begin{array}{l}\text { Bambauer- } \\
\text { Sachse and } \\
\text { Mangold, } \\
2011 ; \\
\text { Goyette et } \\
\text { al., } \\
2010\end{array}$ \\
\hline $\begin{array}{l}\text { Third Party } \\
\text { Recognition }\end{array}$ & & $\begin{array}{l}\text { 1. Kualitas lembaga sertifikasi } \\
\text { 2. Pekerjaan third party recognition } \\
\text { 3. Perlindungan third party recognition }\end{array}$ & Likert 1-5 & $\begin{array}{l}\text { (Cheung \& } \\
\text { Lee, 2006) }\end{array}$ \\
\hline $\begin{array}{l}\text { Legal } \\
\text { Framework }\end{array}$ & $\begin{array}{l}\text { Kerangka hukum } \\
\text { untuk melindungi } \\
\text { konsumen dalam } \\
\text { bertransaksi } \\
\text { online }\end{array}$ & $\begin{array}{l}\text { 1. Prosedur perilaku konsumen } \\
\text { 2. UU Perlindungan Konsumen } \\
\text { 3. Kerangka Hukum UU Perlindungan } \\
\text { Konsumen }\end{array}$ & Likert 1-5 & $\begin{array}{l}\text { (Cheung \& } \\
\text { Lee, 2006) }\end{array}$ \\
\hline Trust & $\begin{array}{l}\text { Keyakinan } \\
\text { konsumen } \\
\text { terhadap sesuatu }\end{array}$ & $\begin{array}{l}\text { 1. Pengalaman } \\
\text { 2. Informasi } \\
\text { 3. Keamanan media sosial } \\
\text { 4. Kepercayaan online } \\
\text { 5. Kepuasan internet }\end{array}$ & Likert 1-5 & $\begin{array}{l}\text { Connolly } \\
\text { and } \\
\text { Bannister, } \\
2007 \text {; } \\
\text { Harris and } \\
\text { Goode, } \\
2004\end{array}$ \\
\hline $\begin{array}{l}\text { Purchase } \\
\text { Decision } \\
\text { Involvement }\end{array}$ & $\begin{array}{l}\text { pengaruh terhadap } \\
\text { proses keputusan } \\
\text { pembelian }\end{array}$ & $\begin{array}{l}\text { 1. Pilihan dalam membeli } \\
\text { 2. Ketepatan memilih produk } \\
\text { 3. Hasil pilihan produk }\end{array}$ & Likert 1-5 & $\begin{array}{l}\text { Mittal, } \\
1989\end{array}$ \\
\hline
\end{tabular}

\section{METODE RISET}

Pada penelitian ini akan dilakukan analisis data secara kuantitatif. Data didapatkan dari penyebaran kuesioner kepada responden. Adapun yang menjadi responden penelitian ini adalah generasi milenial (usia 18-34 tahun).
Teknik pengumpulan sampel dilakukan dengan non probability sampling dengan purposive sampling. Sampel akan dipilih dengan peluang yang tidak sama dan menargetkan responden yang akan diteliti adalah mahasiswa S1 dan S2 di Kota Padang. Penelitian akan dilakukan dengan menggunakan skala Likert. Kuesioner adalah 
daftar pertanyaan tertulis yang telah dirumuskan sebelumnya yang akan responden jawab, biasanya dalam alternative yang didefinisikan dengan jelas (Sekaran \& Bougie, 2013). Operasionalisasi variabel penelitian dapat terlihat pada tabel 1 .

Berdasarkan data dalam penelitian ini dianalisis secara kuantitatif melalui metode multivariat teknik Structural Equation Model (SEM) menggunakan program IBM SPSS AMOS 24. Untuk menguji dan mengestimasi secara simultan hubungan antara multiple laten variabel independen dan multiple laten variable dependen dengan banyak indikator serta menguji model dengan efek mediator maupun moderator, model dalam bentuk nonlinear dan kesalahan pengukuran (Latan, 2013)

\section{HASIL DAN PEMBAHASAN}

Uji model measurement adalah menguji hubungan antara indikator dengan variabel laten. Digabungkannya pengujian model struktural dan pengukuran tersebut memungkinkan peneliti untuk menguji measurement error sebagai bagian yang tidak terpisahkan dari SEM serta melakukan analisis faktor bersamaan dengan pengujian hipotesis
(Bollen, 1989). Pada uji measurement model didapat hasil Chi-square sebesar 633.141, Degrees of freedom sebesar 309 dan Probability level sebesar 0,000.

Model struktural menunjukkan chisquare sebesar 633,141 dan degree of freedom sebesar 309. Pada Tabel 2 menunjukkan bahwa nilai Chi Square, CMIN/DF, CFI TLI, IFI, RMSEA, dan RME sudah sesuai dengan kriteria. Model penelitian sudah baik karena secara keseluruhan nilai goodness of fit-nya sudah masuk kategori good fit dan nilai RMSEA kurang dari 0,08 sehingga tidak perlu dilakukan modifikasi model.

\section{Uji Normalitas Data}

Evaluasi normalitas data dilakukan dengan menggunakan nilai critical ratio skewness value sebesar $\pm 2,58$ pada tingkat signifikansi $0,01 \quad(1 \%)$. Data dikatakan berdistribusi normal jika nilai critical ratio skewness value di bawah $\pm 2,58$ (Ghozali, 2005).

Berdasarkan hasil perhitungan, semua indikator nilai critical ratio skewness valuenya di bawah $\pm 2,58$. Data yang dari indikator berdistribusi normal dan layak untuk digunakan. 
Tabel 2. Goodness of Fit Index

\begin{tabular}{lll}
\hline Kriteria & Hasil & Keterangan \\
\hline Chi Square & 633.141 & Good Fit \\
P value & 0.000 & Not Fit \\
CMIN/DF & 2.049 & Good Fit \\
GFI & 0.827 & Marginal Fit \\
AGFI & 0.789 & Not Fit \\
CFI & 0.941 & Good Fit \\
TLI & 0.933 & Good Fit \\
NFI & 0.891 & Marginal Fit \\
IFI & 0.941 & Good Fit \\
RMSEA & 0.070 & Good Fit \\
RMR & 0.037 & Good Fit \\
\hline
\end{tabular}

Tabel 3. Uji Validitas

\begin{tabular}{lcc}
\hline \multicolumn{1}{c}{ Variabel } & AVE & $\begin{array}{c}\text { Akar } \\
\text { AVE }\end{array}$ \\
\hline Social Media Usage & 0.689 & 0.830 \\
EWOM & 0.724 & 0.850 \\
Third Party Recognition & 0.821 & 0.906 \\
Legal Framework & 0.810 & 0.90 \\
Trust & 0.738 & 0.859 \\
Purchase Decision & 0.785 & 0.886 \\
Involvement & & \\
\hline
\end{tabular}

\section{Uji Discriminant Validity}

Berikut adalah hasil output diagram structural pada AMOS dengan menggunakan software IBM SPSS AMOS 24 pada Tabel 3 untuk uji validitas.

Pengujian discriminate validity dengan menggunakan nilai AVE dilakukan dengan cara membandingkan nilai akar dari AVE setiap konstruk dengan korelasi antara konstruk dengan konstruk lainnya. Direkomendasikan nilai AVE harus lebih besar dari 0,50 (Hair Jr et al, 2014). Berdasarkan Tabel 3 menunjukkan bahwa nilai
Tabel 4. Regression Weight

\begin{tabular}{|c|c|c|c|c|c|c|}
\hline & & Estimate & S.E & C.R & $\mathrm{P}$ & Label \\
\hline & $\begin{array}{l}\text { Trust } \\
\leftarrow\end{array}$ & .200 & .088 & 2.277 & .023 & Par_21 \\
\hline & SMU & & & & & \\
\hline & $\begin{array}{l}\text { Trust } \\
\leftarrow\end{array}$ & .345 & .097 & 3.549 & $* * *$ & Par_22 \\
\hline & EWOM & & & & & \\
\hline & $\begin{array}{l}\text { Trust } \\
\leftarrow \text { I.F }\end{array}$ & 207 & .068 & 3.053 & .002 & Par_29 \\
\hline & $\begin{array}{l}\text { Trust } \\
\leftarrow \text { TPR }\end{array}$ & 180 & .067 & 2.676 & .007 & Par_36 \\
\hline H5 & $\begin{array}{l}\text { PDI } \leftarrow \\
\text { TPR }\end{array}$ & .031 & .077 & .400 & .689 & Par_23 \\
\hline $\mathrm{H} 4$ & $\begin{array}{l}\text { PDI } \\
\leftarrow \text { IF }\end{array}$ & .179 & .080 & 2.249 & .025 & Par_24 \\
\hline H5 & $\begin{array}{l}\text { PDI } \leftarrow \\
\text { Trust }\end{array}$ & .438 & .099 & 4.402 & $* * *$ & Par_26 \\
\hline $\mathrm{H} 2$ & $\begin{array}{l}\text { PDI } \leftarrow \\
\text { EWOM }\end{array}$ & .245 & .113 & 2.171 & .030 & Par_27 \\
\hline H1 & $\begin{array}{l}\mathrm{PDI} \leftarrow \\
\text { SMU }\end{array}$ & .216 & .098 & 2.202 & .028 & Par_28 \\
\hline
\end{tabular}

akar dari AVE setiap konstruk lebih besar dengan korelasi antara konstruk dengan konstruk lainnya. Sehingga dapat disimpulkan memiliki discriminant validity yang baik.

Kriteria goodness of fit model structural yang diestimasi dapat terpenuhi, maka tahap selanjutnya adalah analisis terhadap hubungan structural model (pengujian hipotesis) seperti yang ditunjukkan pada Gambar 1 sebelumnya. Hubungan antar konstruk dalam hipotesis ditunjukkan oleh nilai regression weights pada Tabel 4.

Pengaruh antara social media usage terhadap purchase decision involvement dapat disimpulkan berdasarkan pengujian hipotesis yang dilakukan terbukti bahwa ada pengaruh 
yang searah antara social media usage dengan purchase decision involvement. Media sosial merupakan tempat untuk mencari informasi, ketika informasi didapatkan melalui internet dengan platform media sosial akan membuat individu menaruh perhatian terhadap suatu merek atau produk. Variabel social media usage menunjukkan pengaruh positif terhadap purchase decision involvement yang ditunjukkan dengan nilai estimasi sebesar 0.216 .

Adanya pengaruh yang searah antara eWOM dengan purchase decision involvement. Adanya pengalaman yang dirasakan oleh individu yang pernah melakukan pembelian produk sebelumnya secara online akan membuat rasa tertarik atau minat individu lain untuk menggunakan produk tersebut meningkat. Ini didukung oleh nilai estimasi yang positif yaitu sebesar 0,245.

Tidak terdapat pengaruh antara variabel third party recognition dengan purchase decision involvement. Pihak ketiga akan membuat individu akan merasa tertarik terhadap suatu produk, tetapi pada penelitian menunjukkan bahwa tidak adanya hubungan langsung antara third party recognition terhadap purchase decision involvement.

Terdapat pengaruh searah antara variabel legal framework terhadap purchase decision involvement. Legal framework akan membuat inividu menaruh minat terhadap suatu merek. Individu sadar akan etika dan payung hukum dalam melakukan transaksi online. Pengaruh positif yang ada didapatkan dari nilai estimasi positif yaitu sebesar 0,179 .

Terdapat pengaruh positif antara variabel trust terhadap purchase decision involvement. Kepercayaan positif mempengaruhi niat pembelian konsumen online. Kepercayaan akan membuat konsumen online semakin yakin dengan sistem transaksi yang ditawarkan oleh penjual. Kepercayaan berpengaruh positif terhadap purchase decision involvement, nilai estimasi yang didapatkan sebesar 0,438 .

Terdapat pengaruh antara variabel social media usage terhadap purchase decision involvement yang dimediasi oleh trust. Hal ini menunjukkan bahwa kepercayaan individu akan dipengaruhi oleh seberapa seringnya individu menggunakan media sosial, sehingga 
dari media sosial akan terjadi minat terhadap suatu merek.

Pengaruh antara variabel eWOM terhadap purchase decision involvement yang dimediasi oleh variabel trust. Kepercayaan terhadap $e W O M$ sebagai tambahan informasi dalam memutuskan keputusan pembelian akan membuat minat konsumen terhadap merek akan meningkat.

Pengaruh antara variabel third party recognition terhadap purchase decision involvement yang dimediasi oleh variabel trust. Pihak ketiga yang objektif diperlukan untuk mempromosikan kepercayaan konsumen dalam melakukan pembelian. Pengakuan pihak ketiga memberi konsumen rasa aman dalam belanja internet. Dari kepercayaan pada platform yang disediakan oleh pihak ketiga akan membuat konsumen merasa memiliki keterlibatan dalam keputusan pembelian. Semakin konsumen percaya terhadap kehadiran pihak ketiga akan semakin besar minat konsumen dalam melakukan pembelian.

Terdapat pengaruh antara variabel legal framework terhadap purchase decision involvement yang dimediasi oleh variabel trust. Legal framework merupakan perlindungan hukum untuk pengguna online yang melakukan transaksi elektronik. Adanya hubungan antara legal framework dan trust, sehingga konsumen berminat pada suatu merek.

\section{KESIMPULAN DAN SARAN}

Pada penelitian ini didapatkan pengaruh antara social media usage, eWOM, dan legal framework terhadap purchase decision involvement secara langsung. Media social merupakan salah satu tempat untuk generasi milenial mencari informasi. Informasi yang didapatkan akan membuat sesorang menaruh perhatian terhadap suatu merek atau produk. Pengalaman terhadap pemakaian produk atau jasa yang telah pernah dirasakan oleh pengguna sebelumnya, akan membuat calon pembeli merasa tertarik akan suatu merek. Generasi milenial peduli pada kerangka hukum yang melindungi hak konsumen saat akan melakukan transaksi online. Hal ini berdampak kepada minat konsumen terhadap suatu merek. Dalam penelitian ini contohnya pada Traveloka.

Sementara itu tidak terdapat pengaruh secara langsung antara variabel third party recognition dengan purchase decision 
involvement. Kehadiran pihak ketiga secara langsung tidak mempengaruhi minat dan ketertarikan generasi milenial terhadap suatu merek. Hal ini disebabkan salah satunya karena kurangnya informasi tentang kinerja pihak ketiga. Ketika dimediasi oleh trust, variabel third party recognition mempunyai pengaruh terhadap purchase decision involvement. Kesimpulan yang dapat diambil, kehadiran pihak ketiga akan sangat mempengaruhi generasi millennial ketika mereka percaya terhadap kehadiran lembaga pihak ketiga.

Generasi millennial akan membagikan pengalaman positif yang mereka dapatkan saat menggunakan jasa Traveloka. Traveloka harus menjaga dan meningkatkan kualitas jasa yang diberikan, seperti kecepatan respon dalam menanggapi keluhan konsumen dan harga yang ditawarkan bersaing serta memberikan kemudahan dalam bertransaksi.
Kehadiran pihak ketiga di masa depan pada Traveloka agar lebih menonjol ketiga sebagai referensi konsumen dalam melakukan keputusan pembelian. Khususnya generasi milenial yang merupakan generasi paling banyak populasinya saat ini.

Keterbatasan yang peneliti temukan dalam penelitian ini adalah banyak responden yang tidak fokus dalam mengisi kuesioner offline sehingga ada jawaban yang dikosongkan. Pada penyebaran kuesioner online responden banyak yang tidak mengisi kuesioner, sehingga untuk ke depannya diperlukan daya tarik tersendiri untuk mengisi kuesioner online. Variabel third party recognition dan legal framework, mungkin jarang diketahui oleh responden, tetapi untuk legal framework menunjukkan adanya pengaruh positif terhadap purchase decision involvement. 


\section{DAFTAR PUSTAKA}

APJII. 2016. Hasil Survei Internet APJII 2017. https://apjii.or.id/survei2017

Bojang, I. (2017). Determinants of Trust in B2C e-commerce and their relationship with consumer online trust: A case of ekaterinburg, Russian Federation, 22(May).

Bollen, K. . (1989). Structural Equations With Latent Variables. New York: John Wiley \& Sons.

Cheung, C. M. K., \& Lee, M. K. O. (2006). Understanding Consumer Trust in Internet Shopping: A Multidisciplinary Approach, 57(4), 479-492. https://doi.org/10.1002/asi

Doorn, J. Van, Mittal, V., \& Nass, S. (2010). Customer Engagement Behavior: Theoretical Foundations and Research Directions Customer Engagement Behavior: Theoretical Foundations and Research Directions, (August). https://doi.org/10.1177/1094670510375599

Gefen, D., Karahanna, E., \& Straub, D. W. (2003). Trust and TAM in online shopping: an integrate mode, 27(1), 51-90.

Ghozali, I. (2005). Aplikasi Analisis Multivariate Dengan Program SPSS. Semarang: Badan Penerbit Universitas Diponegoro.

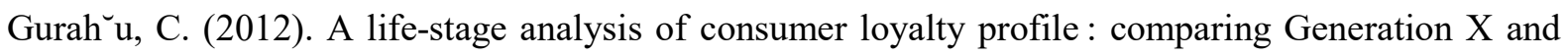
Millennial consumers, 29(2), 103-113. https://doi.org/10.1108/07363761211206357

Hair Jr, J. F., Black, W. C., Babin, B. J., \& Anderson, R. E. (2014). Multivariate Data Analysis (Seventh Ed). Harlow: Pearson New International Edition.

Hennig-Thurau, T., Gwinner, K. P., Walsh, G., \& Gremler, D. D. (2004). Electronic word-of-mouth via consumer-opinion platforms: What motivates consumers to articulate themselves on the Internet? Journal of Interactive Marketing, 18(1), 38-52. https://doi.org/10.1002/dir.10073

Houston, M. J. (2016). A Paradigm for Research on Consumer Involvement, (June).

Jalilvand, M. R., \& Samiei, N. (2012). The effect of electronic word of mouth on brand image and purchase intention An empirical study in the automobile. 
https://doi.org/10.1108/02634501211231946

Jarvenpaa, S. L., \& Vitale, M. R. (2000). Consumer trust in an Internet Store Consumer trust in an Internet store $*$. https://doi.org/10.1023/A

Jin, D., Gon, W., \& Soo, J. (2007). A perceptual mapping of online travel agencies and preference attributes, 28, 591-603. https://doi.org/10.1016/j.tourman.2006.04.022

Kamal, F. F. (1999). Cyber Business (ed 3). Jakarta: Alex Media Komputindo.

Koufaris, M., \& Hampton-sosa, W. (2004). The development of initial trust in an online company by new customers, 41, 377-397. https://doi.org/10.1016/j.im.2003.08.004

Krishnamurthy, S., \& Dou, W. (2008). Note from Special Issue Editors, 37-41. https://doi.org/10.1080/15252019.2008.10722137

Lee, M. K. O., \& Turban, E. (2001). A Trust Model for Consumer Internet Shopping, (May).

Ma, L., Sun, B., \& Kekre, S. (2015). The Squeaky Wheel Gets the Grease - An Empirical Analysis of Customer Voice and Firm Intervention on Twitter, (September).

Mcknight, D. H., Choudhury, V., \& Kacmar, C. (2002). Developing and Validating Trust Measures for e-Commerce : An Integrative Typology, 334-359.

Meskaran, F., Ismail, Z., \& Shanmugam, B. (2013). Online Purchase Intention : Effects of Trust and Security Perception, 7(6), 307-315.

Mittal, B. (1989). Measuring Purchase-Decision Involvement, 147-162.

Parment, A. (2013). Generation Y vs . Baby Boomers : Shopping behavior, buyer involvement and implications for retailing. Journal of Retailing and Consumer Services, 20(2), 189-199. https://doi.org/10.1016/j.jretconser.2012.12.001

Pavlou, P. A., \& Gefen, D. (2004). Building Effective Online Marketplaces with Institution-Based Trust, 15(1), 37-59. https://doi.org/10.1287/isre. 
Purnasari, H., \& Yuliando, H. (2015). How Relationship Quality on Customer Commitment Influences Positive e-WOM, 3, 149-153. https://doi.org/10.1016/j.aaspro.2015.01.029

Raman, A. (2015). Web Services and e-Shopping Decisions : A Study on Malaysian e-Consumer Web Services and e-Shopping Decisions : A Study on Malaysian e-Consumer, (December).

Ray, I., Ray, I., \& Natarajan, N. (2005). An anonymous and failure resilient fair-exchange ecommerce protocol, 39, 267-292. https://doi.org/10.1016/j.dss.2003.10.011

Salam, A. F., Rao, H. R., \& Pegels, C. C. (2003). Consumer-Perceived Risk in E-Commerce Transactions, 46(12), 325-332.

Sekaran, U., \& Bougie, R. (2013). Research Methods for Business : A Skill Building Approach (Seventh Ed). New York: Wiley.

Sofie, Y. (2003). Consumer Protection and its Legal Instruments,. Bandung: PT. Citra Aditya Bakti.

Stewart, K. J. (2001). Trust Transfer on the World Wide Web, (June).

Wahyuni, E. S. (2003). Aspect of Certificate and its Connection to Consumer Protection. Bandung: PT. Citra Aditya Bakti.

wu, P. C. s., \& Wang, Y. C. (2011). The influences of electronic word-of-mouth message appeal and message source credibility on brand attitude. Asia Pacific Journal of Marketing and Logistics, 23(4), 448-472. https://doi.org/10.1108/13555851111165020

You, Y., Vadakkepatt, G. G., \& Joshi, A. M. (2015). A Meta-Analysis of Electronic Word-of-Mouth Elasticity. Journal of Marketing, 79(2), 19-39. https://doi.org/10.1509/jm.14.0169

Zhang, J. Q., Craciun, G., \& Shin, D. (2010). When does electronic word-of-mouth matter? A study of consumer product reviews is. Journal of Business Research, 63(12), 1336-1341. https://doi.org/10.1016/j.jbusres.2009.12.011 